Short Communication

\section{COMBINED CYTOGENETIC EFFECTS OF BENZENE AND RADIATION ON CULTURED HUMAN LYMPHOCYTES}

\author{
ベンゼン投与㧊よび放射線照射の複合による \\ 培養ヒトリンパ球染色体の変化
}

It is frequently reported that occupational exposure to ambient benzene can induce chromosome aberrations $^{1,2)}$ in peripheral blood lymphocytes as well as in the bone-marrow cells. Experimental studies have been accumulated on induced chromosome changes ${ }^{3-5)}$ in bone-marrow cells or in peripheral lymphocytes. Similar chromosome changes are also found in the workers exposed to radiation accidentally $^{6,7)}$ and A-bomb survivors in Hiroshima and Nagasaki. ${ }^{8,9)}$

There is a increasing possibility of synergistic effect of mutagenic or clastogenic agents in the environmental circumstances. ${ }^{10,11)}$ Then, in the present study the author observed in vitro combined effects of benzene and radiation on chromosome aberrations in human peripheral lymphocytes after 53 hours incubation.

\section{Materials and Methods}

About $0.3 \mathrm{ml}$ of peripheral blood freshly drawn from a normal male adult was suspended in approximately $5 \mathrm{ml}$ of culture medium which consisted of medium TC-199 $(80 \%)$ and fetal calf serum $(20 \%)$ with 500 units of penicillin and $0.5 \mathrm{mg}$ of streptomycin. In the first study, benzene was added to the culture media with final concentrations of 3.0 $\times 10^{-3} \mathrm{M}, 1.0 \times 10^{-3} \mathrm{M}, 2.0 \times 10^{-4} \mathrm{M}$ and $4.0 \times 10^{-5} \mathrm{M}$. Immediately after this treatment, caps of the vessels were tightened. In the second, benzene was added at levels of $1.0 \times 10^{-3} \mathrm{M}, 2.0 \times 10^{-4} \mathrm{M}$, and 4.0 $\times 10^{-5} \mathrm{M}$ and the caps were tightened. The blood samples in the benzene-added media and controls were exposed to gamma-rays emitted from $4000 \mathrm{Ci}$ ${ }^{137} \mathrm{Cs}$ source at room temperature. Total dose was $100 \mathrm{rad}$ at a dose-rate of $33-35 \mathrm{R} / \mathrm{min}$ calibrated in advance.

All samples were initiated with phytohemagglutinin-P and incubated at $37^{\circ} \mathrm{C}$ for 53 hours including the last 6-hr treatment with deacetylmethyl colchicine (Colcemid-CIBA) at the final concentration of $0.5 \mu \mathrm{g} / \mathrm{ml}$. Chromosome preparations were made according to the standard air-drying method ${ }^{12)}$ by a slight modification and were stained with Giemsa.

Microphotographs were made for randomly selected cells with sufficiently separated chromosomes.
On these pictures structural chromosome aberrations were recorded as dicentrics, rings, acentric fragments, breaks and gaps (of both chromosome-type and chromatid-type) with reference to numerical analysis of the chromosome-set, consultig the original slide when necessary.

\section{Results}

Structural chromosomal aberrations per cell and percentage of the cells with structural chromosome change induced by benzene exposure are tabulated in Table 1. None of dicentrics and rings was observed. At relatively higher concentrations of benzene, all types of deletions except chromosometype breaks, and percentage of the aberrant cells increased significantly as statistically indicated, though chromosome-type deletions were tested by chi-square method with Yates' correction.

Results indicated that leukocytes in their late SG2 stage may have higher chromosomal sensitivity to benzene than those in the G0-G1 stage, as the frequency of chromatid-type deletions was very higher than that of chromosome-type ones.

Structural chromosome changes induced by 100 rad irradiation soon after the addition of benzene are described in Table 2 as dicentrics \& rings per cell, chromosome-type deletions per cell and chromatid-type deletions per cell. There are also shown percentages of the cells with chromosomala berrations whose increase had a good dose-response relationship with benzene concentration.

\section{Discussion}

On chromosome effect of benzene, Koizumi et al. ${ }^{5)}$ reported previously that there was $21.8 \%$ of cells with breaks and gaps at benzene concentration of $1.1 \times 10^{-3} \mathrm{M}$ but there was only $15.3 \%$ of the aberrant cells at a higher concentration of $2.2 \times 10^{-3} \mathrm{M}$, thougt in controls it was $8.5 \%$, in 72 -hr cultured human leukocytes. This is because some aberrant cells may not survive to the next cell division. ${ }^{13)}$ Most of the metaphase leukocytes harvested after 72 hours of incubation were in their second division in culture from the initiation with PHA. The present study showed a good relationship between benzene concentration and percentage of the cells with structural chromosome aberrations (Table 1), as leukocytes were harvested in their first division after 53 hours of culture. ${ }^{13)}$

Gaps per cell, obtained by subtracting breaks per cell from breaks and gaps per cell, was increased remarkably according to the benzene concentration in both tables. The data were suggestive of a mechanism of benzene on chromosomal aberrations if gaps observed were caused mainly by indirect effect on histone or other connector proteins which consti- 
Table 1. Effects of benzene on chromosome aberrations of 53-hr cultured human lymphocytes (Mean \pm S.D.).

\begin{tabular}{ccccccc}
\hline $\begin{array}{c}\text { Concentration } \\
\text { of benzene } \\
\text { treated }\end{array}$ & $\begin{array}{c}\text { Number } \\
\text { of cells } \\
\text { examined }\end{array}$ & $\begin{array}{c}\text { Cel1s with } \\
\text { aberration } \\
(\%)\end{array}$ & $\begin{array}{c}\text { Chromosome-type aberration } \\
\text { Breaks } \\
\text { per cell }\end{array}$ & $\begin{array}{c}\text { Breaks \& gaps } \\
\text { per cell }\end{array}$ & $\begin{array}{c}\text { Chromatid-type aberration } \\
\text { Breaks } \\
\text { per cell }\end{array}$ & $\begin{array}{c}\text { Breaks \& gaps } \\
\text { per cell }\end{array}$ \\
\hline Control & 236 & $10.2 \pm 2.1$ & 0 & $0.004 \pm 0.004$ & $0.025 \pm 0.010$ & $0.106 \pm 0.021$ \\
$4.0 \times 10^{-5} \mathrm{M}$ & 146 & $15.1 \pm 3.2$ & 0 & $0.027 \pm 0.014$ & $0.048 \pm 0.018$ & $0.144 \pm 0.031$ \\
$2.0 \times 10^{-4} \mathrm{M}$ & 135 & $18.5 \pm 3.7^{*}$ & $0.007 \pm 0.007$ & $0.030 \pm 0.015$ & $0.052 \pm 0.020$ & $0.170 \pm 0.035$ \\
$1.0 \times 10^{-3} \mathrm{M}$ & 159 & $22.0 \pm 3.7^{* *}$ & 0 & $0.031 \pm 0.014$ & $0.050 \pm 0.020$ & $0.208 \pm 0.036^{* *}$ \\
$3.0 \times 10^{-3} \mathrm{M}$ & 145 & $29.0 \pm 4.5^{* *}$ & $0.014 \pm 0.010$ & $0.048 \pm 0.018^{*}$ & $0.076 \pm 0.023^{*}$ & $0.303 \pm 0.046^{* *}$ \\
\hline
\end{tabular}

Cells with aberration ${ }^{\dagger}$; cells with chromosome- and/or chromat1d-type breaks \& gaps.

* significant at $P<0.05, * *$ significant at $P<0.01$ ( chi-square test).

Table 2. Combined effects of benzene and radiation of chromosome aberrations of 53-hr cultured human lymphocytes (Mean \pm S.D.).

\begin{tabular}{|c|c|c|c|c|c|c|c|}
\hline \multirow{2}{*}{$\begin{array}{c}\text { Concentration } \\
\text { of benzene } \\
\text { treated }\end{array}$} & \multirow{2}{*}{$\begin{array}{l}\text { Number } \\
\text { of cells } \\
\text { examined }\end{array}$} & \multirow{2}{*}{$\begin{array}{c}\text { Cells with } \\
\text { aberration } \\
\text { (\%) }\end{array}$} & \multirow{2}{*}{$\begin{array}{l}\text { Dicentrics } \\
\text { and rings } \\
\text { per cell }\end{array}$} & \multicolumn{2}{|c|}{ Chromosome-type deletion } & \multicolumn{2}{|c|}{ Chromatid-type deletion } \\
\hline & & & & $\begin{array}{c}\text { Breaks } \\
\quad \text { per cell }\end{array}$ & $\begin{array}{r}\text { Breaks \& gaps } \\
\text { per cell } \\
\end{array}$ & $\begin{array}{c}\text { Breaks } \\
\text { per cell }\end{array}$ & $\begin{array}{c}\text { Breaks \& gaps } \\
\text { per cel1 }\end{array}$ \\
\hline $\begin{array}{l}\text { Control } \\
\text { (100rad only) }\end{array}$ & 211 & $29.4 \pm 3.7$ & $0.100 \pm 0.022$ & $0.085 \pm 0.020$ & $0.118 \pm 0.024$ & $0.052 \pm 0.016$ & $0.104 \pm 0.022$ \\
\hline $\begin{array}{c}4.0 \times 10^{-5} \mathrm{M} \\
(+100 \mathrm{rad})\end{array}$ & 128 & $34.4 \pm 5.2$ & $0.117 \pm 0.030$ & $0.109 \pm 0.029$ & $0.133 \pm 0.032$ & $0.063 \pm 0.022$ & $0.172 \pm 0.037$ \\
\hline $\begin{array}{r}2.0 \times 10^{-4} \mathrm{M} \\
(+100 \mathrm{rad})\end{array}$ & 142 & $40.9 \pm 5.4^{*}$ & $0.162 \pm 0.034$ & $0.099 \pm 0.026$ & $0.134 \pm 0.031$ & $0.085 \pm 0.024$ & $0.211 \pm 0.039^{* *}$ \\
\hline $\begin{array}{r}1.0 \times 10^{-3} \mathrm{M} \\
(+100 \mathrm{rad})\end{array}$ & 144 & $50.5 \pm 5.9^{\star *}$ & $0.215 \pm 0.039^{\star \star}$ & $0.118 \pm 0.029$ & $0.174 \pm 0.035$ & $0.104 \pm 0.027$ & $0.257 \pm 0.042^{\star *}$ \\
\hline
\end{tabular}

tute chromosomes in combination with DNA strands. The combined effect of benzene and radiation on chromosomes seems to be synergistic only in dicentrics and rings, and to be additive in the other aberrations. To make the mechanism of the synergistic effect clear, further study is being prepared.

The author is grateful to Prof. A. Koizumi for his leading, to Mr. Y. Tachibana for kind technical assistance and advice, and to Dr. Y. Dobashi for valuable advice.

\section{References}

1) Tough, I. M., Smith, P. G., Court Brown, W. M. and Harnden, D. G.: Chromosome studies on workers exposed to atmospheric benzene, Europ. J. Cancer, 6: 49-55, 1970.

2) Forni, A., Pacifico, E. and Limonta, A.: Chromosome studies in workers exposed to benzene or toluene or both, Arch. Environ. Health, 22: 373378, 1971.

3) Kissling, M. and Speck, B.: Chromosome aberrations in experimental intoxication, Helv. med. Acta, 36: 59-66, 1971.

4) Philip, P. and Jensen, M. K.: Benzene induced chromosome abnormalities in rat bone marrow cells, Acta path. microbiol. scand. Section A, 78: 489-490, 1970.

5) Koizumi, A., Dobashi, Y., Tachibana, Y., Tsuda, K. and Katsunuma, H.: Cytokinetic and cytogenetic changes in cultured human leucocytes and HeLa cells induced by benzene, Ind. Health, 12: 23-29, 1974.

6) Dolphin, G. W.: Biological dosimetry with particular reference to chromosome aberration anal. ysis, in "Handling of radiation accidents"-Proceedings of a symposium, IAEA, Vienna, 215224, 1969.

7) Ishihara, T., Kohno, S., Hirashima, K., Kumatori, T., Sugiyama, H. and Kurisu, A.: Chromosome aberrations in persons accidentally exposed to ${ }^{192}$ Ir gamma-rays, J. Rad. Res., 14: 328-335, 1973.

8) Sasaki, M.S. and Miyata, H.: Biological dosimetry in atomic bomb survivors, Nature, 220: 1189 $-1193,1968$

9) Ishihara, T. and Kumatori, T.: Chromosome studies on Japanese exposed to radiation resulting from nuclear bomb explosion, in "Human radiation cytogenetics" (Evans, H. J., Court Brown, W. M. and McLean, A. S., eds.), 144-166, NorthHolland Pub. Co., Amsterdam, 1967.

10) Hollaendar, A.: Chemical Mutagens, Plenum Press, N.Y.-London, 1971.

11) WHO: Health hazards of the human environ. ment, WHO, Geneva, 1972.

12) Buckton, K. E. and Evans, H. J.: Methods for the analysis of human chromosome aberrations, WHO, Geneva, 1973.

13) Bender, M. A. and Brewen, J. G.: Factors influencing chromosome aberration yield in the human peripheral leukocyte system, Mutation Res., 8: 383-399, 1969.

\section{Kanehisa MORIMOTO}

Department of Human Ecology, School of Health Sciences, Faculty of Medicine, University of Tokyo

\section{森本兼量}

\section{東京大学医学部保健学科人類生態学教室}

Received for publication October 31, 1974 